DOSSIER: DIGITAL PATHS: BODIES, DESIRES, VISIBILITIES

\title{
Unfaithful narratives: methodological and affective notes about experiences of masculinity in a dating website for married people*
}

Larissa Pelúcio**

\begin{abstract}
Internet, sex and secret are a triad that launches many methodological and ethical challenges for those who conduct researches in the digital media field requiring reinvention of already consolidated techniques. On Ashley Madison website, which is oriented to promote dates between married people, I became immersed in the dynamics of these relations in which the tension among new communication technologies, masculinities, conjugalities and affections market led me to discuss the researcher's place and role as interlocutor and confident; being aware of the emotional dimension of media proved to be a crucial factor on the production of discourse and of the evident textualization of oneself.
\end{abstract}

Key Words: Ashley Madison, Digital Media, Contemporary Conjugalities, Masculinity, Online Research Methodology.

* Received March 5, 2015, approved April 16, 2015. Translated by Juliana Laet. Reviewed by Richard Miskolci. Research funded by Fundação de Amparo à Pesquisa do Estado de São Paulo (Fapesp).

** PhD in Social Sciences, Anthropology teacher at Unesp-FAAC in Bauru, SP, Brazil. larissapelucio@gmail.com 
I did not think so, but I was having sex with them. This was a voyeur sex, virtual sex, in which the reading eyes and typing fingers excite the imagination of my contumacious collaborators. Paulo, university professor, 54 years old, São Paulo state resident, fills the pages that he sends me by email telling me about his adventures since he started using the paid services of Ashley Madison, a Canadian website that was launched in Brazil in 2011 promising hot hookups and safe relations outside marriage. "Life is short. Enjoy an affair" (Ashley Madison, 2014), is the inviting slogan of AM, as my collaborators use to spell the website's name.

Ricardo says he is jealous of Paulo ${ }^{1}$. I share some stories and impressions with Ricardo, because, since the beginning of this research that started in the middle of 2011, he was the most intriguing informant that I had. I like his analysis and his acid writing marked by a lack of any condescendence for the reader. Ricardo says he never wants to meet me in person because he does not exist. Who does exist is a 48 year-old man who threw away a career and is facing professional difficulties as an independent contractor, who no longer has sexual interest in his wife although he respects her profoundly as a woman and as a companion. Ricardo wants to receive my e-mails in order to keep playing this provocative personage; he wants to be, as he calls himself, my "guinea pig". I play this game for pleasure and academic interests. I conclude that without this combination the communication does not work. The research with digital media is demanding and there must be pleasure within the immersion.

Every day I must visit the website. I need to sign up on different websites in order to conduct comparative analysis and more productive choices to investigate the proposals. I need to connect at different times of the day to check whether there are any changes regarding the access according to day time. I have to check the messages sent by the website hosts. And to copy, paste, systematize the messages organizing my user profiles. I need to check the users' profiles that "saw" me that day, count down the

1 The names mentioned herein are fictional. 
winks and key requests. ${ }^{2}$ I have to check emails and answer them. I organize the emails in named folders and keep the content of conversations chronologically organized. Blue: the emails they write to me, red: the emails I sent them back. This is an extremely absorbing routine which made me elect, in the end, only Ashley Madison $^{3}$ to work with, the website that gave me more quantitative and qualitative results at the time. Its interface in clear colors and easy access tabs to different tools made the access very dynamic and opened up the possibility to collect more information from the services available with no charge for female users.

I registered two user profiles in the website, paying attention to the details of a cheater: a back turned picture, but sufficiently seductive from my point of view: I lowered my age, putting me away from the "abjection" line of the fifties ${ }^{4}$; I offered only partial information which took me to the line between a detailed user

2 The website Ashley Madison has a tab that allows me to see what users viewed my profile during the previous week. The winks are a tool with no costs for the users used to draw the attention of the other users to someone own webpage. The key request refers to a request sent by message by a user who wants to have access to the private pictures of some other user, in that case, my own photos. It is possible to know that a person has private photos in her/his webpage without, however, be able to see them. I kept photos in my private gallery in order to prove that I really existed and that I had a face, since that in my profile picture, opened to everyone, I was turning back.

3 I followed with my student Mariana Cervi the dynamics of different date websites and we chose Ashley Madison because it had a higher number of users and interaction tools what made it more productive since it generated a better number of access to our profiles and of messages. At the time, the Canadian website counted, according to the data provided by it, 17 million users in the world and 1 million of Brazilian users among them.

4 At the same time, two of my students created profiles with different ages on the website. One of them was Mari_28, student, blond; they did not upload any photos or put any other details to be clicked that would offer more information about the user. After one day, there were more than 40 approaches through messages and winks ( $a$ tool offered by the website which allows the user to send a virtual wink, showing interest, this is not a paid service). On the other hand, another profile, also incomplete, named Verinha6.2 stayed unvisited and never received any kind of approach. 
profile and another one with more dry information. At AM, as on other websites of the same kind, the user provides data of his/her sexual preferences, his/her romantic desires and hobbies, filling closed questionnaires that end up often as an open space in which the user can freely type (with a pre-established number of characters) something about him/herself.

Creating a user profile in dating websites is a highly rationalized process no matter if we are conducting a research. Registering is to build a kind of "computational version of oneself" (Illouz, 2011:111). It mobilizes efforts for synthesis and commodification. What is the best way to advertise ourselves? How to differentiate oneself in the wide catalogues in which these websites have transformed themselves into? How to translate ichnographically the best part of ourselves? Living this experience took me closer to the people on the website. I was faced with ethical challenges once my profile had to be sufficiently credible and attractive, but it could not be a "trap". It would not be honest to create expectations for the possible dates only to disappoint them with my research intentions. The solution I found, after testing the website for a while using a profile with a nickname similar to my own name (Lari Silva), was to create another profile, as Pesquisadora2013 (Researcher2013).

Pesquisadora2013 was also a "trap", once in my presentation sentence I chose the ambiguous "exploring the field... searching for collaborators", instead of saying that it was a webpage of an anthropologist researching contemporary conjugalities, intimacy and technologies. I reflected on this aspect a lot, but I considered that this kind of previous announcement would create an immediate bias, which would prevent me from knowing how many men would be interested in a profile like mine: a married woman, 45 years old, with the back turned to the photo while looking at the sea, that declared herself a good listener and 
said to be opened to new discoveries, and was interested in visiting swing houses. ${ }^{5}$

Surprisingly many men accessed my profile sending me custom messages or "winks" and even virtual gifts like roses and puppies. Apart from the "winks" all other gifts are paid services to male users. That situation made my commitment even more complicated because people accused me of making them spending money in vain and told me I should be more honest in my presentation on the website.

Every time I received custom messages, I mean, messages that were written by the users, I answered them also with a custom message telling them about my research. Some of them never wrote me again. Others were rude and few others, precisely 32 of them, agreed to exchange emails with me and with some of them this exchange lasted for months. This article is about these mature men aged between 38 and 70 years old. Better, this essay is about masculinities, conjugality and technologies, whose field was consolidated in a website called Ashley Madison. This is a website oriented to sexual and love encounters among married people who want to remain married. However, this is also a text about methodology and ethics in researches oriented toward the uses of digital media. ${ }^{6}$

5 This was a real interest because the swing experience seemed to me to be a counterpoint to the confidential and secure cheating that the website proposed, once it presupposes that the relation with other partners, preferably couples, will be consensual and the partners will be aware and present in the sexual intercourse. Thus, I wanted to see if I would find swingers in there. If there were any indeed, none got in touch with me.

6 "It is possible to define digital media as means that allow creating selected relational networks inside a kind of sexual and amorous market which ascended from the so-called Sexual Revolution and now has just come to be seen through websites and applications" (Miskolci, in this dossier). 


\section{Affection and technologies}

I came to notice that the men who agreed to participate in this research had a very similar social and cultural profile: almost all of them were self-employed or worked with intellectual activities (journalists, university professors, lawyers), they had remarkable cultural capital, they were literature and poetry connoisseurs, good writing lovers, and they had traveled a lot. In short, they were men who could be considered "successful people" in the mainstream values.

Still, there was something about solitude ${ }^{7}$ in the answers they emailed me. Avoiding victimizing them, I began to consider that our conversation about happy family lives, which were tensioned by the existential emptiness of those middle-aged men, could be a seduction feature, calling upon not only my solidarity, making me a kind of accomplice of their small treasons, but, especially, a captive reader of the reports they sent me by email and an interested interlocutor. Adilson writes me: "I think it is interesting to be able to share these big secrets with someone". Days before he gave me another clue also by email: "I like this communication. Maybe because you certainly don't belong to this environment, despite being so interested in it". Not being a native, using an anthropological term, was advantageous exactly because it presupposed another kind of hearing about what people were doing on the website.

The emails were central as a means of communication for this research. I had worked with digital media before. In my doctoral research ${ }^{8}$ I collected significant part of my data in

\footnotetext{
7 Many emails were reports in a confessional tone about fears, anxieties, desires and the lack of dialogue about these emotions with their female partners. Also, they used to write me about the difficulties on finding a reliable friend to listen to their feelings about marriage, sexual and professional issues.

8 This research was about the AIDS preventive model and its reception by travestis who prostitute themselves. It led me to seek contact with their customers. It happened online, specifically through the disabled social media, Orkut, in which I could establish the first contacts with men who assumed to be travestis'
} 
conversations I had on Orkut communities ${ }^{9}$, emails discussions lists, blog posts and MSN instant messaging. The latter, because of its synchronicity, became at that moment a great tool for interview which often happened to be spontaneous conversations. It cost me a lot to realize that for this research that tool would not fit my needs exactly because of its synchronicity and the possibilities it opened for my interlocutors to ask for webcam conversations which eventually caused persistent harassments ${ }^{10}$, but those situations helped me rethink the means of dialogue that I would use and make me realize that those means could also base the exercising of a certain masculinity. ${ }^{11}$

Reasonably, the men with whom I communicated through emails were those who believed on elaborated prose as a seduction mechanism but also as a way of textualizing their adventures and misadventures into narratives that enabled a selfevaluation made by the narrator himself and also by me, who was co-opted as an active listener, someone to respond to. In other words, they had someone to interact with them. Sherry Turkle (2011), in her research about the increasing use of media for personal communication, notes that the rapid interaction, the response to electronic messages received from people with whom we are not intimate with or even with people we never met outside

customers. We started to talk using MSN after exchanging many messages and emails. At some point, one of these men told me about the meetings of the socalled T-Lovers (travestis and transsexuals lovers). That is how I started to merge online with offline incursions and began to get along with a group who called itself T-Lovers. The research, funded by FAPESP, resulted in the book Abjeção $e$ Desejo - uma etnografia travesti sobre o modelo preventivo de aids (Annablume, 2009).

9 Orkut was a very popular social network website in Brazil. It was surpassed by Facebook in the beginning of 2012 and was definitively closed in 2014.

${ }^{10}$ During my doctoral research, in 2003 up to 2007, I used a dial-up internet and the connection services were far more expensive than nowadays. Features like webcams and microphones had to be bought separately and the internet was slower than today, which made the work with images and sounds much less attractive than it came to be.

${ }^{11}$ I will discuss this topic further on. 
the screen, is an enchantment factor. This is a different kind of interaction in relation to face to face contact, or, as Baym (2010:06) states, body to body. What is different about this communication, for many of my interlocutors, has to do exactly with the lack of specific social cues that force them to guess who a person is through written language.

Nancy Baym (2010:59) writes that "people show feeling and immediacy, have fun, and build and reinforce social structures even in the leanest of text-only media", so that those social cues we use on offline routine can be implemented with some efficiency even in an email. Júlio César, one of my first contacts on the AM website, used his offline experiences to evaluate women he knew online. On the other hand, just like some of the other men who talked to me, Júlio César liked the dilution of those cues that the lean media promote.

What I like about it is what happens behind our eyes: who will this person be, how is she, what does she like, what does she, is she telling the truth in the emails, does she ask the same questions I do? I think that the seduction has to be complete: only the body is too little, only the soul is too platonic.

Adilson, the only collaborator I met in person, also enjoys the pleasure of that self-textualization game: "Discovering the person gradually culminating in a personal encounter is really magic (or can be)". "Can be", because, in the end, the cues are not there. "People can be very different when we meet, because things like charm, intelligence, timing, perspicacity, taste, etc... We can only realize personally", he concludes. Still, he is delighted with the tasty emails he receives from one of his dates on the website, his "friend from Santos" 12 , a woman who is more than 50 year old, who amuses him with the stories of her day to day life. When he saw the photo of her breasts, which she "prankishly" sent him, he was moved. He would not have approached her if it

${ }^{12}$ A big coastal city in the State of São Paulo, Brazil. 
wasn't for her verbal sagacity, he confesses me, and, then, share with me one of her chronicles by email.

The uses assigned to each media change over time because the very people who use them attribute them different meanings. We might just remember our personal and professional experience with the telephone, for example. For those who were adolescents during the 70s and 80s that technology carried a sense that has been largely lost nowadays, not only for the new generations, as well as to other people who have a number of other media available for both leisure and for work.

Indeed, this is a line that was quite blurred in the routine of my interlocutors. As many of them had smartphones it was easier for them to use portability and the possibility of internet for flirting and arranging dates with their suitors and/or lovers, even when they were at work or on the move. I confess that this connected mobility used to invade my day in a disturbing way. ${ }^{13}$

The new supports for these technologies such as cell phones with internet access and tablets have become personal objects not usually shared. Thus, protected by passwords or by tacit codes that stipulate the private use of certain devices, my interlocutors learned that communication made in transit could provide, also, fortuitous encounters at work breaks. In one of the emails he sent me Geraldo justified the hasty writing: "Oh, excuse the lack of commas but I am writing you at lunch and I did not have the time to review the punctuation".

\footnotetext{
${ }^{13}$ The idea of being always on call made me anxious. I thought that if I did not reply I could lose important data or, worse, I could lose a collaborator hardly acquired. Dealing methodologically with these new research tools and shaky territories has been picky (I will return to this further on).
} 
Lia, the only woman I was in touch with and that I met ${ }^{14}$ tells me about her escapes during lunch time or in the evening, after work time, to "fancy" motels with her favorite lover, who she called affectionately Leão (Lion), in reference to the nickname of a former Brazilian goalkeeper, who was famous among his women fans, among other attributes, because of his beautiful strong legs.

Leão travelled a lot; Lia too had a job that required frequent displacements. She is 46 and unmarried, unlike her adventure's partner, but she says so, "saying that they don't think I want to marry them. I don't want to. But this kind of relationship has a downside, right? And we must learn that we will have to face Christmas alone, weekends too and many Skype conversations [laughs]". The relationship became possible, and muy caliente, in Lia's account, because digital media, portability and connectivity made it so. "We had sex through Skype". A different kind of sex of that she is having, also using Skype, with her foreign boyfriend. Lia gave up on Leão and some other men she flirted with and met occasionally. Her boyfriend lives abroad and she brings to their relationship many things she learned about emotions and technologies.

I like Bruna Bumachar's argument: "the choice of technologies not only reveals the language of control, but also expresses the language of emotions" (2011:93). As I have pointed out earlier, the emails granted me more control over the ways of interacting with those men. More than that, the emails allowed me to come back to the messages before answering them, unlike the instant messaging service MSN. Still, there was the possibility of

\footnotetext{
${ }^{14}$ Lia found me during recurrent searches she did on Google looking for references about Ashley Madison in order to keep up about the website and to optimize her use of it. I was interviewed for Revista da Unesp (http://www.unesp.br/aci_ses/revista_unespciencia/acervo/40/te-perdoo) about the research I was conducting. Thus, crossing the search words that she used to apply, Lia found the article and, then, my email. She sent me a message telling me she wanted to tell her stories to someone and saw me as an interesting interlocutor. Therefore, we scheduled three meetings of three hours duration each; all of them happened in São Paulo where she lives.
} 
being alone while immersing in the screen textualizing our subjectivities (Illouz, 2011) yearning for the receiver's reading. I found that there is pleasure in this process, not only for me. Adilson, a literature lover, 49 years old, professionally working with Exact Sciences, also felt some excitement in those permutation games which would precede the meetings what would make them even more interesting. In reference to a great love he had in the late 1990's at a chat room on UOL website, he writes: "The emails, the messages, the waiting, the pleasure of writing and reading, the diners, the tours... everything was part of something that could have transformed my life".

The sociologist and psychoanalyst Sherry Turkle theorizing about the relation between the writing and the personal expectations of changes and transformations declares in an interview:

In an important correspondence by mail and other forms of electronic communication, there is, on the one hand, the intensity and the fantasy of this kind of instant communication, but, unlikely a conversation, you can read and re-read a message. A supplement of meaning joins the power of conversation. There is an aspect of the order of participation in online conversation which can be frequent and can facilitate the coordination among different and geographically dispersed people (Turkle, 1999:121).

I live this power in me through the pleasure my interlocutors said to obtain using the digital communication technologies to intensify emotions which were numb to many among them. 


\section{After all, what kind of man gives up "hunting" women to be "researched"? ${ }^{15}$}

It is important to answer Ricardo's question. After all, who are those men that desire to be desired and, curiously, desire to talk about themselves to someone who declares herself "a good listener", but who is actually collecting research data with them?

Most men with whom I interacted with in this research are graduated ones and live in the State of São Paulo. ${ }^{16}$ Only Luiz is from Rio de Janeiro. Only Teo, Aurélio and Fernando (42, 57 and 70 years old, respectively) are not committed. The first two have recently separated; the latter has been a widower for three years. Despite having a girlfriend, Fernando, the older man that I talked with, does not feel like he is really committed. Three among the other 25 profiles have girlfriends or fiancées, the others are married. The average wedding time is about 13 years. ${ }^{17}$

The websites point to profound changes in marital relations which have undergone a transformation in gender relations, but also through the possibilities that the Internet as a cultural artifact and as culture itself (Hine, 2004) presents, especially for a generation that still deals with the Internet as a relative novelty for romantic purposes. One should also consider, as many authors have already pointed out, that online and offline are spaces that determine each other reciprocally. The emergence of online services for married people dating and cheating asks for accurate consideration of the present, of the off-screen life.

My collaborators would argue that romantic love ruled the engagements that today seem to bore them. They are faithful to it, more than to their wives, and they are looking for a reunion with

\footnotetext{
${ }^{15}$ This is an interrogation that Ricardo sent to the researcher in one of his long messages.

16 The richest and most populous State of Brazil. The State of São Paulo has over 40 million inhabitants and its economy represents around 1/3 of the Brazilian GDP. It is very urban and with a strong concentration of its population in the services sector.

${ }^{17}$ No data about racial issues was obtained.
} 
that feeling described as rapturous and theorized by Social Sciences at least since Georg Simmel's (2001 [1909]) essays.

The faithfulness to this relationship model leads them to bet on the permanence of marital life as a secure foundation in a changing world. Marriage does not seem to be an institution which makes them unhappy. This institution is closer to the classical Durkheim's view of sociology of the family which takes marriage as an institution capable of protecting the individuals in an anomic world (Féres-Carneiro, 1998:s/p).

Despite cultivating the individual freedom, romantic love lost its transgressive and erotic qualities (Costa, 2005), in order to fit the social logic of gender and family alliance. As Chaves (2006:835) suggests this love is a 'domesticated romantic love', that differs from the original, which was more savage and erotic (Aboim, 2009:108).

In search of that lost dimension of romantic love they signed up in the AM seeking an emotion, among others, that is somewhat vague but which launches a good discussion about contemporary masculinities: feeling alive. This is an expression that acquires different meanings in the writing of eight among the 32 men with whom I interacted more consistently. I chose Ricardo, 46; Adilson, 46; Karl, 41; Paulo, 54; Júlio César, 46; Geraldo, 57; Rogério 53; and Luiz, 48, because they were the ones who wrote longer texts or maintained a more frequent communication with me. Symptomatically, they are also the ones who expressed more clearly the challenges to a model of masculinity that has been transformed by changes in gender relations more markedly in the societies of a Western matrix since the 1960s.

I tell Ricardo that many interlocutors I have give much importance to the writing skills of women they are interested in. While I am writing to him, I think about Luiz who told me de is 'turned off' by crass misspelling. But Karl has the most eloquent text about the capacity of writing seduction. I reproduce an 
excerpt below from one of his messages in which he tells me about the ravishing passion he was living:

We used to talk all the time, only through words. We felt so much desire for each other, a different desire because what erotized this desire were precisely the distance and the words. Always the words (Karl, 41 years old, two marriages, 5 years in the actual marriage [at the time of the research], plastic artist and works with Communications)

Sarcastic, Ricardo does not believe in this "grammatical turn-on". Not even in the possibility of the women subscribed in AM of expressing themselves in a textually fascinating manner. When I ask him if he is seduced by the messages he receives, his answer is caustic and reproduces, unintentionally, the classical dichotomy brain versus body that organized the distribution of power in gender relations in western matrix societies:

You ask me how women textually seduce me (?)... And I tell you that it did not happen, at least not yet. I 'textually seduce' them, seeking in their bodies the sensuality of our face to face meetings. It is interesting to suppose that women in AM could seduce someone using only a keyboard. I guarantee that 'many images and few words' is the form of female expression. Using the keyboard, they send data (not always correct data) about their age, etc. In short, whether they are seduced through 'keyboard' or they make simple contact; they open their Gallery ${ }^{18}$ and show their real power of seduction (Ricardo, 46 years old, married for 23 years at the time of my research, engineer).

\footnotetext{
${ }^{18}$ It refers to Private Gallery, a tab possessed by each user profile in which one can add pictures. These are available on1y if the user grants another user a "key" that is ichnographically represented in this way. The key allows the access to the photographs.
} 
I suspect that Ricardo used to like to cast these provocations precisely to "feel alive" because of his criticism. I imply that the feeling revealed in this phrase is related to the idea of risk and to the notion of masculinity which guide these men. Each one of his provocations made him feel the risk of the interruption of our relation. We even had some disagreements which led to periods of silence in our mailing exchanges.

To some extent, all of them were under some kind of risk: being discovered, falling in love, breaking stable relationships that gave them security. However, many were betting on their ability to manage and control those risks. When they could not do so, they were pleased with the emotions associated to "risk-adventure" (Spink, 2001):

By using the term risk-adventure we are referring, only partially, to new forms of adventure and to new uses of old form of vertigo games. We chose the composed term riskadventure in order to emphasize an important shift of modern meaning of risk that recover adventure as a positive dimension of risk management (Spink, 2001:1278).

It is important to address, even if only tangentially, the relation between the intensified digital media uses, masculinities, conjugalities and risk management. The latter, to men, is strongly associated to the ways they make use of Internet resources. Managing risks in this context is related to the control of information, through monitoring its movement (caution with passwords to prevent access to their devices and profiles); which also requires caution with identity, so the adoption of nick names and the relative parsimony in the disclosure of personal photos; caution on what is revealed and how to do it, for example, paying attention to their writing in order to avoid misunderstandings; regulating the amount of personal data disclosed and shared, accumulating and systematizing information about other people in order to ensure a more comfortable movement among available communication website tools, emails, MSN messenger, still active 
at the time the research was made, Skype and also text messaging (in that case, in order to avoid confusing the women who they are talking to, mixing up their nick names or stories told, among others).

As risk managers, these men end up expressing on the experiences they narrate basic elements of late modernity theorized by Ulrich Beck (1993) with the concept of "risk society". According to Beck, the risk society is sustained by the triad globalization, individualization and reflexivity. The first brings as sine qua non condition the development of electronic media; individualization is associated to the untraditionalization of institutions like family, for instance; the reflectivity would be the "susceptibility to the chronic revision of the most part of the aspects of social activity and relations with nature, under the light of new information" (Beck cited Spink 2001:1282).

One of the evident marks of late modernity associated with other aspects pointed by Beck is perhaps the displacements related to gender relations field. My interlocutors show that in several ways. Somehow, managing, controlling, monitoring, or having the feeling that they do so give them a feeling of control and autonomy which links them to traditional models of masculinity in an universe in which these powers are diluted (there are more men than women seeking extramarital adventures; they are men over 40 , living in a society which appreciate youth and in which the active and insertive sex is a symbol of masculinity and virility; these men show some difficulties to deal with female sexual autonomy as well as entrenched values of masculinity, such as the non demonstration of their emotions or the desire to do so).

It is not about adhering to the "victimizing" speech of masculinity which punctuated the gender studies in this field (Oliveira, 1998), but to be provoked by the anguishes these men express in their writing where it is possible to verify the unwillingness (or the lack of reflection) to change the rules and conventions which guide and legitimate asymmetric gender relations: 
There are also many disappointments, not only with the service offered by the website, but also with the types of women who they have encountered when connecting to the platforms. They seem "too hussy", "troubled", "coming from unhappy relationships", "willing" to go straight to wanting to get to the good stuff right away, thus, destabilizing the gender expectations that some of these men have.

On the other hand, the feeling that life is short and that they are not "George Clooney, Eike Batista or Mark Zuckerberg" makes them believe that the most exciting women present in restrict cheating market are out of reach which settles a great frustration feeling and confronting them with their fear of being refuted and deprecated because of their age, physical type and socioeconomic condition. To some extent, they all seem to run some emasculation risk, the same risk they would take if they stayed attached to marital routine $^{19}$ (Pelúcio e Cervi, 2013:47-48).

\section{Life is short, enjoy an affair ${ }^{20}$}

With no tactical resources to manage the imponderable, many of my interlocutors fell in love with women they met in AM. Others cannot stand their sequential denials and/or indifference regarding the messages they sent and their online user's profiles. The refusal that comes from the Internet is no less painful and can be measured.

Some of those men soon realized that "enjoying an affair" was not an easy task as the website's advertising used to promise. Enjoy an affair, as the second part of AM's slogan authorizes ("Life is short, enjoy an affair"), or trying to enjoy it put forth profound

\footnotetext{
${ }^{19}$ As married men, many of my interlocutors report they feel like they lost something that is important to "a man", such as: freedom on sociability situations, guilt free sexual conquest exercises, permission to commit abuse whether in alcohol consumption or sexual adventures, greater control over their time and money are some of the elements I associate with the emasculation feeling.

${ }^{20}$ Ashley Madison's slogan.
} 
moral dramas which included also questionings about gender relations, social class and age.

I spoke to men over 40 years old that did not have emotional connections with the Internet and its social resources during their youth. Although they could easily manage the tools for communication in digital media they were not sure if they managed the somewhat fluid sociability codes operating in many of these environments. Neither they were sure that their strategies to deal with marriage were the best they could employ. Even so, many of them seemed to realize that, yes, "life is short", but there are many ways to improve their experiences, so they can have the impression of expanding time. Digital media could help them to do so.

This is the way it happened with Geraldo who worked in the 1990s in Kuwait where he lived for 12 years. Culturally isolated, he found that the UOL chatrooms could find company and excitement for the boredom of night shifts. Currently, through AM, he intends to 'raise flight' in sex:

When I was still in Kuwait, we had some relationship problems in marriage, and I ended up getting involved with someone on the Internet. This time it got so serious that I used to call her almost every day, sometimes at the cost of an international call. I said I was working after hours, just to get out and call her. These conversations lasted for months until I came to Brazil for vacations. I should travel from Salvador to São Paulo to date her. But then I gave up again. I knew that if I met her, my marriage would run a serious risk and I lacked the courage to do so. [...] I love my wife and our relationship, including sex, gets better everyday, especially after Kuwait, maybe because when we were there we had to support each other and share everything. I think that this situation contributed to fortify our friendship and trust (Geraldo, 57 years old, 32 years of marriage at the time of this research, systems analyst). 
Talking about their domestic and marital lives was a taboo. In general they were reluctant in talking about this subject. Thus, data about their wives and their family lives were collected from short mentions in which the woman, with rare exceptions, was recognized as a companion, good mother and, in some occasions, a successful professional. Therefore, the problem was not with the wives but with marriage as an institution that stains the hegemonic and contemporary values about masculinity, youth and purchasing power.

Being mature men devaluated them in the affects' market which could be compensated with good conversation and some erudition but it was not always enough to ensure they would seduce someone. Jorge, 62 , was one of the oldest men with whom I exchanged messages. He showed me an excerpt from an email he received from one of the women he met on the website and in person. He described her as

A clever woman with a very clear and objective purpose regarding our relationship. Our "talk" was always at a high level, with no bad language or explicit sexual intentions, and it evolved until our first meeting which happened last week.

You can read her response to our meeting below:

Hello my dear Aryan man...

How are you doing? I hope you're doing fine...

Well...I want you to know that I enjoyed very much meeting you... because, in the end, in these days, it is very hard to meet someone we can trust, somebody with whom we can enjoy pleasant conversations and have some affinities.

However, as you said: "you prefer a hurtful truth than a lie"...the fact is that you are not what I am looking for on the website...I'm sorry. And yes, I lied when I said it was the place which didn't allow us to "kiss", but actually, I didn't feel like doing so. 
Paul, $54^{21}$, university professor, somewhat overweight, unlike Jorge, showed me a list of his achievements, that Ricardo, with whom I exchanged many of my views about my other "guineas pigs" 22 , did not believe in: "You know that male lies are fantastic, right?", he nudged me, still talking about Paulo as his narratives "rival" that bounded and wanted to keep me faithful to him in that universe of supposed infidels.

Adilson could also be included among my favorites with his captivating writing, great stories and torrid feelings and romances. I met him personally. I thought about Ricardo at once, who wisely preferred we kept being good in keyboard. I do not doubt Adilson's adventures who was also surprised with our silence during our meeting. To me, he was one among those who best expressed the search for feeling alive now that life seemed so stable:

Deep inside I miss humor, art and culture in my relationship. If this is the cause, I would never risk to say so, after all, each of us is such a complex being and with so many "voids" that seeking in the partner so deep explanation is at least cowardice... (Adilson, 46, married for 22 years at the time of the research, chemist).

He looked for sex with other women, but not only this, I guess. I think that most of my 32 interlocutors wanted to feel "men" living these online incursions and their possible offline outcomes. I use the word men because I work with the hypothesis that they seek to exercise a masculinity that puts them in the tension between the "family man", tamed by fusional couple

\footnotetext{
${ }^{21}$ Paulo sent me the link to his Lattes curriculum where I could see his picture. This attitude was very important as it showed he trusted me and wanted to narrow our bonds.

${ }^{22}$ I always kept the secrecy concerning their names and even their nicknames. Exchanging views on other users was a research strategy in many instances, as it made my collaborators to expose their opinions on others and thus to reveal more about themselves.
} 
model $^{23}$, and the "individual man", autonomous, who values the personal dimension of their own projects, not subordinating them to the ideal of a conjoint well-fare (Aboim, 2010:185):

One way or another it seems to be difficult for men, especially those that live within the modernist framework of the couple associative construction, to manage the multiple references they face. They feel the tensions that arise on the one hand, from the abandonment of traditional masculinity centered on the home provider, on the authority and on an ethic of responsibility, in favor of gender equality and the reconfiguration of themselves in the family; they feel, on the other hand, the difficulties of creating a 'montage' of several masculinity references, struggling with various ambiguities and inversions of traditional gender relations. $\mathrm{He}$ is a man who feminizes himself on the one hand, accumulating traditional feminine powers (despite of the final barrier imposed by maternity symbology), he is a man who turns feminine traditional male categories, and he is a man who feels the tensions trying to overcome the gap between values and practices of inequality in the couple experience (Aboim, 2012:202).

\footnotetext{
${ }^{23}$ In a general way, the construction of the fusional couple, conjugalized and headed to the familiar group, composes an important tendency of family desinstitutionalization and, more than that, of male inclusion in private life. It composes, in a general way, a true movement from "provider-man", institutionalist and regulative, to "partner man", relationalist and democratic (Adams and Coltrane, 2005). As we will see, the construction of companionship on male composes a process crossed by difficulties and tensions issued by a traditional masculinity model that demands men a professional investment and an identity still strongly attached to public sphere roles. The permanent bricolage woven between male involvement ideal on conjugal and parental dynamics and the role as the family breadwinner remains, in many cases, generating tensions and difficulties (Aboim, 2010:166-167).
} 
In relation to the different marital systems categorized by Sofia Aboim based on her research conducted with 37 married men, with children, of different social classes in Portugal, my interlocutors would be better identified with the conjugality model she calls "unequal associative" since the gender asymmetries are present generating tensions that they try to cope with different resources, including the search for partners outside marriage, without wishing, however, to have lovers.

\title{
Digital sensibilities
}

\begin{abstract}
Larissa,
I'm glad you wrote! I always feel good when I receive your messages. First, here is a "follow-up" regarding my Don Juanuan life and the return of optimism. We spoke about many different people. Well, now let's continue with the chronicles (Paulo, 54, 3 marriages, university professor).
\end{abstract}

There are many women in Paulo's chronicles. He did not know them all through AM, but the computer mediated connections are part of his emotional repertoire:

I use the Internet since it exists. For leisure = flirting (lol). I discovered its possibilities in 1999 when I separated from my wife. It was a novelty and only a few people used it, it was exciting! But when I engaged in serious relationships I left it. Later on, with the "fraternalization" of my marriage, I came back to it... 3 or 4 years ago, when I had few hookups, but it was a bad phase, people that I had nothing to do with. Then, came the AM's phase.

Ricardo also collects "hookups" he gets from the Internet. Although he does not consider them actually pleasant, he faces the websites and chats as boosters of these momentary relationships. Those who did not achieve such a numerical success talk about the qualitative relationships, just as Karl, who is madly in love with an AM user with whom he exchanged emails, messages, phone 
calls and caresses on and offline. Also Geraldo, who is so devoted to his wife, without whom he could never live, collects sparse affairs, but not without feeling guilty for it. The last one he achieved through AM. Adilson, very shy, at least when we met in person, also had wild sex with one of the women he first met online, besides keeping erotic and poetic mailing with many others.

Having sex inside the cumulative or serial sexuality logic (Illouz, 2012) has been part of the new sexual economy since the mid-twentieth century. Having many sexual partners without major moral and social commitments has become possible to men and women in Western matrix societies after 1960. Sexual and Cultural Revolution, in which feminist movements contributed significantly to the shift in the behavior regarding gender relations, "sex appeal" became a valuable symbolic good in the affects' market.

If these changes promoted greater gender symmetry, they also enabled the maintenance and even the deepening of some asymmetries, argues sociologist Eva Illouz (2012), who focuses on heterosexual relationships to show that democratized access to many women, meaning that it was no longer necessary for men to be rich or powerful to multiply their lovers, narrowed the relationship between sexuality and male status. In her own words:

Serial sexuality is attractive to men of all classes because, if access to women is restricted, it function as a sign of man's status o of victory over other men. Male competitiveness, validation, and status were channeled through the realm of sexuality (...) Furthermore, men transferred to sex and sexuality the control they had formerly held in the household, and sexuality became the realm within which they could express and display their authority and their autonomy. Detachment in sexuality came to signal and to organize the broader trope of autonomy and control, and thus, of masculinity. Emotional detachment could be viewed as a metaphor for masculine autonomy, which the 
separation between sex and marriage had encouraged (Illouz, 2012:102-103).

It is a paradox to realize, based on the data collected through mailing with the 32 male users of Ashley Madison website, that the search for cumulative and uncompromising sex does not, in fact, satisfy them. Still, they remain faithful, if not to AM, to digital resources for the exercise of masculinity, to the 'feeling alive' sensation which Ricardo translates to hunting or sport fishing, referring to the search for sexual partners without complications and emotions as derived from the search for predatory and competitive sports, establishing the classical connection proposed by Raewyn Connell (1995) between sports and the establishment of a model of masculinity which the author said to be hegemonic. ${ }^{24}$

I don't count adventures and misadventures, I try to analyze what makes people look for a website to have sex...I've already noticed, for instance, that I want to 'hunt' and not exactly to eat the slaughtered animal (perhaps it's an attempt to restore a broken self-esteem?) (Ricardo)

For Júlio Cesar hunting, or rather, the sensations it causes justifies the continuation of online searches. Although he looks for relationships that end up in "real" sex, the very approaching process via digital media is very exciting:

Why do I access the website? As I told you before: you feel like you have butterflies in your stomach when you're connecting with flesh and bone people that are just like you, they have flaws, virtues, desires and sins. And if (don't

\footnotetext{
${ }^{24}$ The concept has been revised by the author herself, but it is still heuristically powerful because it allows thinking from different social markers of difference which intersect conforming different ways of living in the masculine. It also deals with the power relations involved in the relations of men with one another and with women.
} 
misinterpret) you push the right button the person opens up and tell you about her life. All of us need to talk about ourselves to other people (Júlio César, 46, married for 22 years at the time of this research)

Passionate Karl does not care about accumulating sexual relations, but he is still "addicted" to the emotions he can get as a media user to keep in touch with his beloved, who remains married and have complications to meet him personally:

The possibility of receiving a seducing message at any time or even an unexpected proposal is a "temptation" that has made me lose too much time accessing emails and the website...I don't want it to become an 'addiction'. It distracts me. (Karl)

Somehow I also lived intensely those emotions mediated by communication technologies - yearning for the emails my search partners would send me, cheering for them, despising some among them, laughing with others or fearing for my own excessive exposure. This is because, either as a convincing tactic or to prove my scientific intentions were real, I made available my first and last name, link to my Resumé in Lattes platform, told them a little about my marriage, which made me unprotected in this environment where the true information is modulated, not only because we are used to think that Internet relations are potentially dangerous (Nicolaci da Costa, 2002; Miskolci, 2012), but also because my research deals with secrets. I did reveal some secrets myself, not only as a strategy to humanize me and rouse me some empathy and then get involved in deeper interactions, but because the involvement we have with the exchange of narratives of ourselves ends up building dense relations. So, all of us who research in the sexuality and secrets fields have to let her/himself be seduced by invitations to speak more about ourselves. Our approach is protected by the science aura which is often seen as circumspect, but reliable, and we ask for confessions using 
questions that do not seem to threaten anyone, then we go meddling in the intimacy of our collaborators expecting for more. Often this is the key to enter and stay in the field:

Sometimes, the only way to develop the research field and catapult the production of knowledge is precisely in the invitations research participants make. As if research participants would tell us: "You, researcher that has a gender and a sexuality just like me, come with me and do research about me!" Accepting the invitation is not a compulsory decision: it is a decision that deserves to be the result of a practice of reflected freedom, of exercise of ethics. (....) What is more productive for this research? What is the political relevance of crossing certain limits? (Zago, $2015, \mathrm{~s} / \mathrm{n}$ )

"To what extent the project of a 'sexual anthropology' [...] requires thinking about the specificity of the question of desire?" (Perlongher, 1993:s/n), thus destabilizing the very disciplinary pretension of Anthropology? Answering questions like these requires methodological and ethical (re)elaborations still unusual in the field of academic research, although Néstor Perlongher in 1993, already provoked the ethical and methodological dimension of our desire in the field.

Crossing boundaries does not mean trivializing what is done in the field, nor putting ourselves at risk of physical or moral exposition, nor exposing collaborators, but striving to build a methodology through which we would take into account our body, our gender and our desire as elements to think about the field analytically and methodologically, considering, as Miskolci alerts, systematic and ethical procedures that must be present in any offline scientific work:

What can be brought to scientific and public discourse, even when it is directed to a selected or small audience, from these intimate dialogues that occur in digital media? A provisional response would be that we should only bring in 
what our collaborators have expressly allowed us to do so, yet taking necessary care to never use their real names and/or to provide personal information that could identify them. Even when they suggest or ask us to mention their names we should follow this consolidated ethical procedure. The use of pictures also has to be authorized and employed with parsimony avoiding making people identifiable (Miskolci, 2011:19).

There were 270 pages of emails carefully organized; fifty-five of them were messages I exchanged with Ricardo. I'm always amazed when I go back to them. Among the surprises, I find that I miss him. I have no way to access him. He always wanted to protect himself, even from the results of this research:

I never read your academic pieces of research for protection... my own protection! There is nothing like being analytically overturned inside out to get depressed! Ricardo's farce. Maybe it admits psychoanalytic analysis, but purely behavioral analysis I doubt it. I will confess my curiosity about your work... which is deepened when you claim to be truths inside the lies articulated by the website. Let's see if I agree with the conclusions ... until there! Well, regarding the guys who want to fuck with you, it does not require demonstration. It is part of the website's hypothesis, not the thesis'. (...) It is simple, as I mentioned, it is the act of hunting (and not the hunt itself) that moves the hunter on the website.

Once again I feel the risk-adventure and the desire. Feeling desired. An essential feeling, as I noticed that this is the greatest loyalty factor (and abandonment) to the website's services. I abandoned it.

It is necessary to consider how far we should go in our investigations. In this case, my 32 interlocutors gave me the limit because they also offered me some parameters to realize when data started to be repeated in the writing of other "hunters" and 
"fishermen"; I noticed that the interactions that used to be dynamic became sparse and compulsory (for me), indicating that the website itself was bound to wane, because what starts there unfolds to many other network media and interaction possibilities. It was enough. I stopped being faithful to them.

\section{Bibliography}

ABOIM, S. Da pluralidade dos afetos: trajetórias e orientações amorosas nas conjugalidades contemporâneas. Revista Brasileira de Ciências Sociais, vol.24, no 70, jun. 2009, pp.107-122.

BAym, N. K. Personal Connections in the Digital Age. Cambridge, Polity Press, 2010.

BUMACHAR, B. L. Migração e novas mídias: um diálogo sobre a experiência familiar transnacional de estrangeiras presas em São Paulo e de trabalhadoras filipinas residentes em Londres. Cronos Revista do Programa de Pós-Graduação da UFRN, vol. 12, n 2 , Natal, 2011, pp.75-95.

CASAlEgnO, F. Sherry Turkle: fronteiras do real e do virtual. Revista Famecos, no 11, Porto Alegre, dez. 1999, pp.117-123.

CONNELL, R. Masculinities. Berkeley University of California, 1995.

FÉRES-CARNEIRO, T. Casamento contemporâneo: o difícil convívio da individualidade com a conjugalidade. Psicologia: reflexão e crítica, vol.11, no 2, Porto Alegre, 1998, pp.379-394.

HINE, C. Etnografia Virtual. Barcelona, UOC, Colección Nuevas Tecnologías y Sociedad, 2004.

ILlOUZ, E. Porque duele el amor? Una Explicación sociológica. Madrid, Katz Editores, 2012.

. O amor nos tempos do capitalismo. Rio de Janeiro, Zahar, 2011.

. El consumo de la utopía romántica. El amor y las contradicciones culturales del capitalismo. Madrid, Katz Editores, 2009. 
MISKOLCI, R. Estranhos no paraíso: notas sobre os usos de aplicativos de busca de parceiros sexuais em San Francisco. In: PELÚCIO, L. et.alli. No Emaranhado da Rede: Gênero, sexualidade e mídia - desafios teóricos e metodológicos do presente. São Paulo, Annablume Queer. 2015. No Prelo.

MisKOLCI, R. A Gramática do Armário: notas sobre segredos e mentiras em relações homoeróticas masculinas mediadas digitalmente. In: Pelúcio, L. et.alli. Sexualidade, Gênero e Mídia - Olhares Plurais para o Cotidiano. Marilia, Cultura Acadêmica, 2012, pp.35-52.

MISKOLCI, R. Novas Conexões: notas teórico-metodológicas para pesquisas sobre o uso de mídias digitais. Cronos - Revista do Programa de Pós-Graduação da UFRN. Natal, vol. 12, 2011, pp.922.

NiCOLACI-DA-COSTA, A. M. Internet: a negatividade do discurso da mídia versus a positividade da experiência pessoal. À qual dar crédito? Estudos de Psicologia, vol. 7, nº1, Natal, jan. 2002, pp.25-35.

OliveIRA, P. P. Discursos sobre a masculinidade. Revista Estudos Feministas, ano 6, nº1, Florianópolis-SC, 1998, s/n.

PeluCio, L. e Cervi, M. Traições, Pequenas Mentiras e Internet: conjugalidades contemporâneas e usos de mídias digitais. Revista Científica Gênero na Amazônia, vol. 1, Manaus, 2013, pp.25-51.

PERLONGHER, N. Antropologia das sociedades complexas: identidade e territorialidade, ou como estava vestida Margaret Mead. Revista Brasileira de Ciências Sociais, ano 8, $\mathrm{n}^{\circ}$ 22, São Paulo/ANPOCS, 1993, pp.137-144.

SIMMEL, G. Filosofia do amor. São Paulo, Martins Fontes, 2001.

SPINK, M. J. Tópicos do discurso sobre risco: risco-aventura como metáfora na modernidade tardia. Cadernos de Saúde Pública, n 17 , São Paulo, 2001, pp.1277-1311.

TURKLE, S. Alone Together: why we expect more from technology and less from each other. New York, Basic Books, 2011. 
60 Unfaithful narratives

ZAGO, L. F. Convites e tocaias - Considerações ético-metodológicas sobre pesquisas em sites de relacionamento. In: PELÚCIO, L. et alli. No Emaranhado da Rede: Gênero, sexualidade e mídia - desafios teóricos e metodológicos do presente. São Paulo, Annablume Queer. 2015. No Prelo. 